\title{
The convergences between post Keynesian and developmental approaches: the post Keynesianism applied to emerging countries
}

\author{
As convergências entre as abordagens \\ pós-keynesiana e desenvolvimentista: \\ o pós-keynesianismo aplicado a países emergentes
}

JOÃO VICENTE NOVAES CAMARGO MANNA*,**

\begin{abstract}
RESUMO: A teoria pós-keynesiana muitas vezes é vista de maneira um tanto padronizada, possuindo uma série de atributos comuns a todas as suas vertentes. Porém, é possível pensar-se que o pós-keynesianismo não mantenha precisamente a mesma forma ao tratar de países desenvolvidos e países emergentes. Caso essa teoria se adapte ao tratar de economias emergentes, é possível que esta ganhe contornos semelhantes às políticas econômicas discutidas especificamente para a análise do contexto de subdesenvolvimento, ou seja, as políticas desenvolvimentistas.

PALAVRAS-CHAVE: Macroeconomia; pós-keynesianismo; desenvolvimentismo; novo desenvolvimentismo; história do pensamento econômico.
\end{abstract}

ABSTRACT: Post Keynesian theory is often seen in a somewhat standardized way, possessing a series of attributes common to all its strands. However, it is possible to think that post Keynesianism does not keep the same form when dealing with developed countries and emerging countries. If this theory adapts to the treatment of emerging economies, it is possible that this theory gains similar outlines to the economic policies specifically discussed for the analysis of the context of underdevelopment, that is, developmental policies.

KEYWORDS: Macroeconomics; post Keynesian theory; developmentalism; new developmentalism; history of economic thought.

JEL Classification: B22; O10; O20.

* Doutorando em Economia da Faculdade de Economia e Administração da Universidade de São Paulo - FEA/USP, São Paulo/SP, Brasil. E-mail: joao.manna@usp.br. Orcid: 0000-0002-6125-5950.

** I express my thanks to the professors Pedro Fonseca and Luiz Carlos Bresser-Pereira for the comments on this paper, contributing to its improvement. Submitted: 14/November/2018; Approved: 10/April/2019. 


\section{INTRODUCTION}

In the field of economic science, we can highlight several schools of thought which much can be classified within the so-called heterodox economic thought. In general, all heterodox approaches share a common point: divergence and criticism of the current economic mainstream ${ }^{1}$ - this economic mainstream being characterized by a strong approximation with neoclassical orthodoxy. It is characterized by an analysis based on individuals with maximizing behavior, allowed to be rational and well-informed, generating static equilibria in the search for agents to maximize their utility (Colander, Holt and Rosser, 2004), or, in other words, it is characterized by a hypothetic-deductive method (Bresser-Pereira, 2009). Although we have a broad set of heterodox approaches, such as institutionalism, post Keynesianism, developmentalism, among others, each one opposing orthodox thought they have in common the assumption of agent expectations formed in an environment permeated by uncertainty and the priority to the historical-deductive method where the economist generalizes out of the observation of the regularities and tendencies observed in the reality.

Within this idea that heterodox economic theories can share common theoretical aspects, this study intends to make an analysis to verify what characteristics the post Keynesian theory and the developmental thought can have in common. For this exercise of comparison, it is necessary to think the post Keynesian theory being applied to the study of countries in the condition of economic underdevelopment, once the developmental thought originate in the analysis of this type of context - the developmentalism arises seeking to understand the causes of underdevelopment condition of some economies and think about policies that can make this economies reach the stage of developed economies. Thus, we will try to analyze whether the post Keynesian theory and policy, when applied to emerging countries (considering all countries under conditions of economic underdevelopment as emerging countries) has common aspects to developmental theories and policies and, if so, what are they. The objective of this paper is to verify if the post Keynesian theory is contextualized in the emerging economies context, it develops developmental boundaries - whether post Keynesianism applied to emerging countries could be a kind of intersection between post Keynesian thought and developmental thought. In the first section we will do this analysis both to try to observe possible common features between post Keynesian and developmental thought (with developmentalism as a general concept), and to try to verify the existence of possible common characteristics between post Keynesianism and new developmentalism. To carry out this analysis, an exposition will be made of both more general aspects of post Keynesianism and developmentalism, as well as of more specific theoretical currents within these theoretical approaches, such as the Kaleckian theory, the

\footnotetext{
${ }^{1}$ For a better understanding of the definition of orthodoxy, heterodoxy and mainstream in the economic debate see Colander, Holt and Rosser (2004).
} 
structuralist theory, the new developmentalist theory and even what could be denominated post Keynesian developmentalism.

The second section begins with an exposition of fundamental aspects that define the post Keynesian theory - the basic aspects that are common to all the strands or versions of this line of economic thought. Next, we attach more importance to the work of Kalecki, using mainly as a reference the classic work in which the author distinguishes the economic problems of the developed countries and the underdeveloped countries. The way Kalecki applies his theory to underdeveloped economies - noting that in this paper we will consider the classification of "emerging economies" and "underdeveloped economies" as synonymous - is of great relevance to make the comparison intended in this article. It ends the section stand out some important considerations made by Kaldor.

In the third section we seek to make an explanation about the developmental macroeconomics, since it is the macroeconomic side of this theoretical current that most interests our discussion. For this explanation, we go through some complementary steps. We begin by addressing basic concepts that are dear to all developmental currents. Following, we presented the main aspects of structuralist theory. At the end of the section we focus more on the new developmentalism, which adds structural characteristics and influences of Keynesian theory.

The fourth section presents an analysis that looks for convergent characteristics between post Keynesianism applied to emerging countries and developmentalism. Initially, we sought convergences between the post Keynesian theory and the core aspects common to all developmental strands. In a second moment, we try to be a little more specific and to verify convergences between the characteristics of post Keynesianism (applied to emerging economies) and the new developmentalism. Finally, in the last section, a brief conclusion is made regarding the results obtained from the comparison between post Keynesianism and developmentalism - as a general concept of developmentalism - and between post Keynesianism and new developmentalism.

\section{THE POST KEYNESIAN THEORY}

To analyze the elements in common between the post Keynesian theory and the developmental macroeconomics we must contextualize post Keynesian theory in the environment of underdeveloped countries and verify whether this theoretical framework ends up developing developmental outlines. Firstly, we will highlight the key characteristics of post Keynesian economics, based on the definition that Lavoie (2007) makes to establish the points that differentiate this from the other heterodox schools of the economy (and that also end up differentiating the orthodox thought, with a strong neoclassical bias, from the post Keynesian thought).

Lavoie (2007) defines seven main characteristics: effective demand, dynamic historical time, the possible negative impact of flexible prices, the existence of a monetary economy of production, fundamental uncertainty, contemporary and 
relevant microeconomics and the pluralism of ideas and methods. Among these characteristics, according to the author, two would be essential characteristics: effective demand and dynamic historical time, while the others would be auxiliary. The characteristics considered auxiliary would also be derived from the characteristics established as essential. Starting with the definition of the effective demand aspect, we have that the economy is determined by demand, with supply adapting to demand, both in the short and the long term. In addition, the demand effective principle also states that it is the investment that determines the savings. These aspects go in the opposite direction to that of orthodox economic thought, which one has the idea that supply determines demand and savings determines investment.

As for the notion of dynamic historical time, post Keynesian thought emphasizes the importance of analyzing the dynamics that occurred in the economy when analyzing different equilibrium points, in opposition to the idea of static equilibriums, more common in economic orthodoxy. In the post Keynesian theory does not only matter the equilibrium points that were achieved at different time points, but it is also important to consider the transition between these points and to recognize that the conditions under this transition occurs can affect the equilibrium points. That notion of dynamic historical time can be connected to the idea of the fundamental uncertainty - central feature in Keynes's work, that differs him from the economic orthodoxy. Factors as the non-ergodicity (which will be explained later) and the dynamic historical time appears as base to establish the fundamental uncertainty of Keynes's theory. With respect to the possible negative impact of flexible prices, post Keynesians reject the virtues of the flexible pricing system, the core of neoclassical economic theory, noting that price flexibility can be destabilizing. Post Keynesians tend to minimize the substitution effect importance (where consumer and producer choices are tied to changes in relative prices) rather valuating the income effect, when consumer and producer choices are mainly determined by changes in income and technical progress.

Prices rigidity is not an exclusive principle of post Keynesians. The new Keynesians (orthodox Keynesians) also share the principle of price rigidity. But here it is important to note that this paper is about the relation between the heterodox Keynesians (post Keynesians) thought and the developmentalism. Although the new Keynesians also adopt the price rigidity principle, they leave out central aspects of Keynes's work (Ferrari Filho, 1996). For example, they do not consider the uncertainty in economic environment. The new Keynesian theory is based on an economic world of complete information that permits the formation of rational expectations by the agents. As stressed by Lavoie (2007), new Keynesians develop their thought from the loanable funds theory. Herscovici (2006) points out that loanable funds theory differs from the liquidity preference theory established by Keynes, having this two theories different causality between saving and investment. So, for new Keynesians the saving finances the investment. On the other hand, (as mentioned before) for the post Keynesians - who adopt the liquidity preference theory - investment finances saving.

The existence of a monetary economy of production is the characteristic that 
seeks to highlight that in an economy all values are established in monetary terms. According to post Keynesian theory, models must recognize that contracts are established in cash; it must recognize that firms have debts and households have assets that can cause considerable financial problems due to changes in the liquidity preference of economic agents. In the context of the monetary economy of production we have the characteristic of liquidity preference, always linked to the notion of fundamental uncertainty, that is very different from the concept of risk - which is present in the neoclassical literature, for example, unlike the idea of uncertainty. Risk is probabilistic and can be calculated, unlike uncertainty, which is incalculable (Lavoie, 2007). The fundamental uncertainty characteristic is related to the non-ergodicity of economic processes (Davidson, 2009). Non-ergodicity means that economic agents are not able to obtain an apprenticeship that allows them to be aware of the objective probabilistic distribution of future events. The future is different from the past, that is, past fluctuations will not necessarily occur in the same way in the future.

It is important do stress here that the fundamental uncertainty is a central principle in the Keynes's work and, consequently, in the post Keynesian theory (as mentioned before). Regarding the importance of contemporary microeconomics, post Keynesian theory is characterized by rejecting the convex isoquants, with U-shaped cost and indifference curves, as defined in neoclassical microeconomics. In this work, we will not delve into the principles that rule the post Keynesian microeconomics but, briefly, we can affirm that the rules and behaviors that determine the actions of entrepreneurs and consumers in this microeconomic theory are quite different from the principles that govern the decisions of consumers and entrepreneurs in neoclassical microeconomic theory.

Finally, we have the pluralism of ideas and methods as a characteristic of post Keynesian theory. Post Keynesians draw inspiration from a variety of sources, from economists such as Keynes, Marx, and Kalecki (who will be important later, as we seek to establish points of closeness between developmental theory and post Keynesian theory), Sraffa, Kaldor, and Veblen until authors of other disciplines (such as sociology, political science, history, anthropology and psychology). There is the idea that truth can take on different forms, and all methods, more formalized or less, are acceptable. According to Harcourt and Kriesler (2013), Kalecki is as influential an author as Keynes for many post Keynesian authors, and for some Kalecki would be considered the most important pioneer within post Keynesianism. As pointed out by Lopez, Puchet and Assous (2009), Kalecki should also be considered a pioneer of economic development theory. In this way, considering he developed a theory with developmental aspects, it is necessary to analyze his economic theory so that we can look for the possible points of convergence between post Keynesian theory and developmental thought (when dealing with the context of emerging countries).

In a context of emerging economies, Kalecki (1966) points out that the main problem is to increase investment on a large scale, aiming rather to accelerate the expansion of productive capacity (which is fundamental to the fast growth of na- 
tional income) than generating effective demand. Such a distinction sums up the difference between developed and emerging countries, and Kalecki considered it the main economic problem to be solved. With regard to this increase in the level of investments in emerging economies, the author points out three measures that should be taken: (i) government intervention in the investment sphere (public investment), in order to guarantee the planned volume and structure (planned for a level to accelerate the expansion of productive capacity); (ii) overcoming institutional barriers to the fast growth of agriculture (growth that would be necessary to enable an adequate increase in the supply of essential consumer goods, which would be necessary with an increase in the level of investment), and (iii) taxation for the upper classes of society. All these measures - which, according to Kalecki, would be of fundamental importance to enable the necessary acceleration of productive capacity in order to allow the fast growth of national income - would be better executed if they were organized on a long-term basis, then in an attempt of an abrupt expansion of production capacity.

It could be imagined a representation of the product trajectories of developed and emerging countries over time, where there are two curves representing the cyclical variations of the product of the economies, each one cut by a straight inclined line representing the trend of product growth. This representation could illustrate Kalecki's (1966) idea that the governments of the developed countries would have as main problem to deal with only one movement - that of economic cycles -, trying to maintain the effective demand and to obtain a situation of full employment. Emerging countries governments, on the other hand, would need to deal with two distinct movements: first, the movement to raise the output level of the economy to the level of developed economies (increasing productive capacity) and, secondly, dealing with the cyclical economic fluctuations - looking to sustain effective demand and pursue the level of full employment ${ }^{2}$.

Thus, Kalecki is post Keynesian; he develops an economic theory that could be considered as developmental. as highlighted by Lopez, Puchet and Assous (2009). López, Puchet and Assous (2009) point out that Kalecki had strategies for economic growth in both the short and long term. In the short term, seeking the sufficient domestic demand growth to maintain the full employment of the labor force and capital goods, Kaleckian theory stands out three possibilities of reaching this point: government spending (financed by budget deficits) in public investment or subsidy for mass consumption, stimulation of private investment, and redistribution of the highest classes to the lowest. In the long term, Kalecki defended to increase the rate of accumulation (since he regarded low accumulation as the main problem of underdeveloped economies) to provide the level of investment that would allow the long-term growth needed by emerging countries. Here we can see Kalecki's important contributions to our search of a common nucleus between

\footnotetext{
${ }^{2}$ Note that there may be underemployment at the production level in the underdeveloped economy, as Kalecki points out.
} 
developmentalism and post Keynesianism, but it is required to add an important question brought explicitly in Kaldor's works: the need for industrialization. This point can be noticed in the author's following excerpt:

[...] the key to an accelerated growth of the underdeveloped areas of the world lies in bringing about fundamental changes in both the mental outlook and the technical knowledge and skill of their peasant populations. Economic development will of course invariably involve industrialization (or at any rate the relative growth of secondary and tertiary industries taken together) (Kaldor, 1960: 242)

Kalecki (1966) stresses the need to expand productive capacity in underdeveloped economies without specifying whether this should occur along with an industrialization process, while Kaldor (1960) stresses the importance of this process for the economic growth of underdeveloped countries. When Thirlwall (1983) lists Kaldor's laws, we can point two that are directly related to the development of the industrial sector: (i) the higher growth rate of the manufacturing industry, the higher the growth rate of an economy. and (ii) the greater the industrial sector growth, the greater will be the growth of the labor productivity in this sector. As Lamonica and Feijó (2011) point out, this second law, known as the KaldorVerdoorn law, comes from Kaldor's interpretation of Verdoorn's law. Kaldor establishes the following causal relation between the productivity growth rate and the output growth rate: an increase in demand results in an increase in output, which leads to a productivity increase of scale dynamic economies sector. KaldorVerdoorn's law allows Kaldor's first law to be verified here, explaining the impacts of the interaction between manufacturing industry and the other economy sectors.

\section{THE DEVELOPMENTAL THOUGHT}

Before we begin the discussion about the developmental macroeconomics, it is worth remembering that literature tends to classify developmentalism in different strands. Bresser-Pereira (2016), for example, distinguishes two distinct developmental strands: classical developmentalism and new developmentalism. The new developmentalism will be the more discussed strand in the present analysis ${ }^{3}$, seeking to make the desired comparison of the structuralist macroeconomics present in this strand - but not only present in this theoretical framework (Mattei, 2013) with the post Keynesian theoretical strand. In addition to this comparison, in gen-

\footnotetext{
${ }^{3}$ There will be no detailed discussion about classical developmentalism, presenting here only a brief notion of points that distinguish them from the new developmentalism. Classic developmentalism still relied on the process of industrialization based on import substitution (as opposed to the idea of exportoriented industrialization combined with mass consumption in the domestic market, present in the new developmental theory) (Bresser-Pereira, 2016).
} 
eral lines, the paper presents a comparison between the post Keynesian theory and the general concept of developmentalism.

Here it is important to remember the double character of the developmental theoretical framework. The developmentalism is at the same time: an economic theory and an alternative to the economic liberalism in organizing the capitalism. The developmentalism is a form of making capitalism more efficient - and less unjust, if it is social democratic or progressive. For a discussion about developmental thought it is important bear in mind that there are two fundamental institutions that can act coordinating the economic process: the market and the state. According to the organization form of capitalism, one of these institutions assumes the main role in the coordination of economy. In the economic liberalism, it would be the market, in the developmentalism, it would be the state. The developmental thought understands the markets as a good institution to coordinate competitive activities, but when dealing with big and complex economies, where there are non-competitive industries and where the market fails to establish the right macroeconomic prices - profit rate, interest rate, wage rate, inflation rate and exchange rate -, the economic liberalism shows inefficient in the capitalism coordination (BresserPereira, 2017a).

It is also worth mentioning that the developmental theory is based on historical episodes of economic development (in successful experiences of developmentalism). The new developmental theory, for example, is based on the experiences of East Asian and Latin America. In the case of East Asian, it is based on economies that achieve fast economic growing throughout de 1980s organizing the capitalism in a developmental form - South Korea, Taiwan, Singapore and Hong Kong - contradicting the idea of laissez-faire. These countries used of active industrial polices and a nationalist position. The four Asian "tigers" followed the Japanese growth model. They started adopting the import substitution model, but seeing they were not rich in natural resources - not allowing they base their exports in commodities - and they had small domestic markets, in 1960s these countries gave up this model, fast becoming exporters of manufactures. This way, their economies were gradually opened, with an economic growth process which had involved capable industrial polices and a rigid control of the macroeconomic prices (Bresser-Pereira, 2018).

In the case of Latin America, Mexico and Brazil realized their industrial revolutions from the 1930s to 1970s with developmental states. This technological catching up was realized with these countries having a certain national autonomy which were lost after the foreign debt crisis of the 1980s. After the crisis, Mexico and Brazil implemented a regime of liberal economic policy and experimenting low growth rates after it. For example, between the 1930s and 1970s Brazilian government subsidized the export of manufactured goods and highly taxed imported products. At the same time, taxes on the commodities export helped to stop an overvaluation of the exchange rate, once the Brazilian economy at this period were based on the export of agricultural products (situation that began to change with the mentioned policy related to the import substitution process). This way, that Brazilian experience of developmentalism also neutralized the Dutch disease trig- 
gered by the large commodities export (Bresser-Pereira, 2017a) - the Dutch disease, which is a big concern in the new developmentalism, will be better explained ahead, in the discussion about the aspects of this developmental strand.

Although there are differences between developmental versions, we will start this section by standing out the attributes common to all. According to Fonseca (2014), with the assumption that there is a capitalist economy and intentionality in the quest to overcome underdevelopment, developmentalism has three characteristics: (i) industrialization, (ii) interventionism and (iii) the existence of a national project. Industrialization would be the way to accelerate economic growth, productivity and the diffusion of technical progress, including in the primary sector. Interventionism would be the deliberate intervention by the state to execute a national project. Finally, the existence of a national project would be the existence of an intentional strategy or project focusing on the nation and its future. It is worth saying that a national project should not be understood that there would be a rupture with the international order or repulse to foreign capital, but only that the nation is the focus of the project.

I will now make an analysis of developmental macroeconomics (BresserPereira, Oreiro and Marconi, 2014) or, as Bresser-Pereira (2012) called it originally, "structuralist development macroeconomics"4. According to Prado (2017), the new developmental strand is characterized by bringing together two traditions: post Keynesian and classical developmentalist. It is based on the Keynes and Kalecki as it views aggregate demand as the main variable for the economy's functioning in the short and long term, with investment being the variable that produces growth. At the same time, the characteristic of the structuralist tradition is to assume that development is a process of structural change or productive sophistication that encompasses the national economy environment and society as whole having technology in its base and institutions giving form or organizing society. Bresser-Pereira (2011a), corroborates this idea that the macroeconomics of new developmental thought is a Keynesian structuralist mix. I cannot analyze here all the points raised by Bresser-Pereira, so the main points that lead to consider the new developmental theory as a junction of these two currents will be emphasized.

Initially, we highlight two points of new developmentalism that BresserPereira (2011a) establishes as being about structural changes (structural economic development). First, the author states that economic development is a process of capital accumulation with the incorporation of technical progress that generates increases in productivity and wages or that leads to raising the population's average standard of living. The second point is that productivity growth is a process that takes place within each sector and structurally, through the trans-

\footnotetext{
${ }^{4}$ The original title of the book, Developmental Macroeconomics (2014) was Structuralist Development Macroeconomics. Bresser-Pereira, Oreiro and Marconi changed the title because the editor argued that "structuralism" was an unfamiliar word for the readers.
} 
fer of labor to sectors with higher added value per worker. With respect to this look at the structural question, it is also important to bring a new developmental feature addressed by Bresser-Pereira (2012): the issue of export-oriented industrialization associated to strategic industrial policy. Accordingly, industrial policy will encourage the companies to invest in strategic sectors and companies that were efficient enough to export.

Bresser-Pereira (2011a) emphasizes three factors related to the demand side approach of new developmental thought. He points out that economic development depends on the efficiency of investments (capital-product ratio), which depends on factors such as technological development, education, infrastructure and institutions. Second, he asserts that these factors (which are structural) are supply-side factors and hardly appear as bottlenecks of growth, since insufficient internal demand and lack of access to external demand are recurrent phenomena in middleincome countries that decrease the opportunities for profitable investment. The last of these points is that public investment is recommended for both middle-income countries and poor or non-industrial countries, which will contribute to the total volume of investment and will stimulate private investment. Regarding public investment, Bresser-Pereira (2011a) also adds that, for the state to invest without causing inflation, it must be financially healthy (that is, it must present a reasonably small public debt and have a positive public saving).

Classical developmentalism did not count with the concept of the Dutch disease, which is central in new developmentalism. The Dutch disease is a phenomenon that was named after being identified in the Netherlands in the 1960s, when economists noticed that with the natural gas discovery in the country and its exploration for export, there was an appreciation of the exchange rate, threatening to destroy the country's industrial activity. This problem occurs basically when the economic activity of a country is based on the export of commodities. The consequent appreciation of the current equilibrium exchange rate in relation to the industrial equilibrium, makes industrial activity unfeasible - unless a very unlikely situation occurs: the country with the Dutch disease has industrial activities where it is on the frontier technological of production, but having a productivity higher than the productivity of the competing countries to a degree greater or equal to the overvaluation of the exchange rate caused by the disease. The difference between the current equilibrium exchange rate and the industrial equilibrium exchange rate is the Dutch disease (Bresser-Pereira, 2008).

Among the characteristics of new developmentalism, two stand out. Firstly, the concern that the exchange rate should be competitive (a floating but managed exchange rate aiming at the industrial equilibrium). Thus, exchange rate policy is essential for economic development; a competitive exchange rate stimulates investment in export-oriented activities, more investments generating more domestic savings consequently. 


\section{CONVERGENCES BETWEEN POST KEYNESIAN AND DEVELOPMENTAL THOUGHT}

After the main aspects of new developmentalism (in addition to the general concept of developmentalism) have been highlighted in the previous section, in this section we will highlight the common points between these two theories. We know there are divergent points between post Keynesian and developmental thinking, but here we will focus on the intersection points between them. It is worth remembering that when we refer to the post Keynesian theory, we are dealing with it contextualized to the environment of emerging countries - because, as pointed out earlier, Kalecki's (1966) propositions for emerging and developed countries are different. Here we will make a similar effort to that of Fonseca (2014), who found a nucleus of common attributes (common core) between different types of developmentalism analyzed in his work, but in the attempt to find a common core between the post Keynesian theory inserted in the context of emerging countries and the developmentalism.

In the first place, it is valid to verify if we can find convergences between the Kaleckian theory and the three basic attributes of any developmental trend defined by Fonseca (2014): interventionism, national project and industrialization. Regarding interventionism, we can already put this as a characteristic present in the post Keynesian theory, since this one advocates the realization of public investment (or subsidy to mass consumption) stimulating private investment to solve problems of low aggregate demand levels (counter-cyclical policy). Regarding the aspect of national project, when we observe that Kalecki clearly has an idea that the emerging countries must increase their productive capacity by putting as possibilities for this: government expenditures (in public investment or subsidy for mass consumption), stimulation of private investment or redistributing income (López, Puchet and Assous, 2009); demonstrate a strategy in which the nation is placed as a focus, seeking to increase its productive capacity at the developed countries level. Such a set of possibilities together with Kalecki's (1966) presentation in his work - even considering political and institutional obstacles that should be encountered in carrying out the reforms that were necessary according to him show the existence of a plan that should be executed by the government. In addition, the concern to raise productive capacity and national income at developed country levels suggests that this government-run plan would focus on its nation, looking for raise the country's production and income levels, a national project - as in the concept proposed by Fonseca (2014).

Regarding industrialization as a way of increasing economic growth, productivity and the technical progress diffusion, we cannot say that Kalecki's (1966) theory necessarily has such a concept. The author gives the idea that emerging capitalist economies must raise their productive capacity and national income to the level of developed economies (industrialized countries) and shows concern about increase the level of capital goods but does not explicitly mention an industrialization process. However, thinking about post Keynesian theory more compre- 
hensively, we can mention Kaldor (1960), for whom the economic development process necessarily involves industrialization. In this way, we could say that it is possible to say that the post Keynesian theory (with emphasis on the approaches made by Kalecki and Kaldor) when dealing with emerging economies, shares all three attributes with developmentalism.

Figure 1: Common Core: Post Keynesianism/Developmentalism

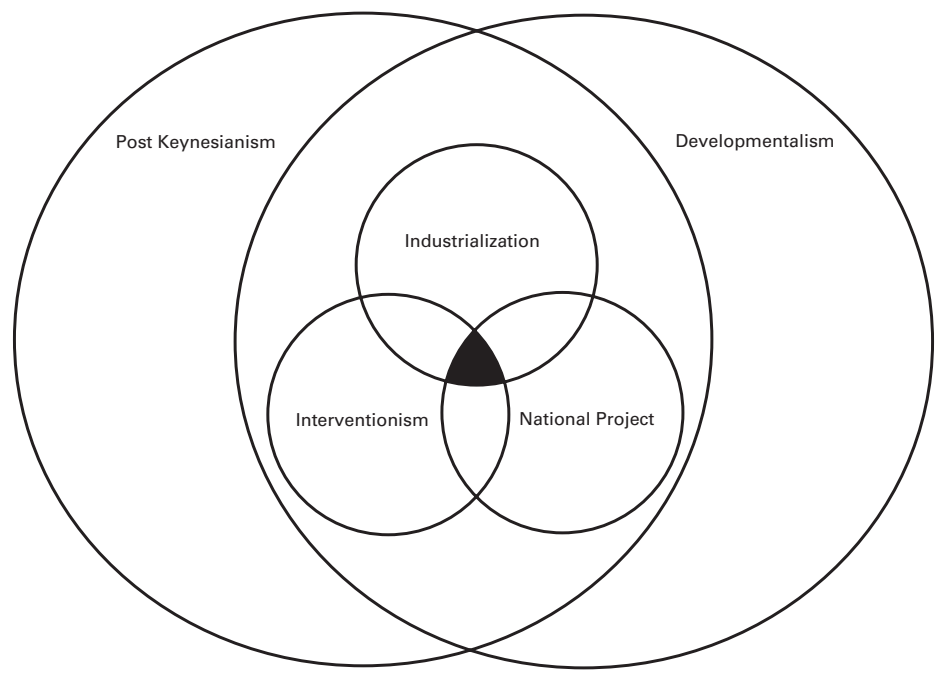

Source: Author's elaboration.

Thus, by analyzing only the attributes common to all developmental strands, we could affirm that by inserting post Keynesian theory in the economic underdevelopment context, it gains developmental outlines, and may contain all the characteristics common to what Fonseca (2014) called the main core of the concept of developmentalism (interventionism, national project and industrialization). If we were to represent this through a Venn diagram - as shown in Figure 1 - we would have circles representing post Keynesianism (as a post Keynesian theory in general), developmentalism and the attributes industrialization, interventionism, and national project. The intersection between the three circles representing the attributes (indicated by the darkest part of the diagram), contained in the intersection between post Keynesianism and developmentalism, represents a common core that could be defined as "post Keynesianism applied to emerging countries" (this concept core).

Now, seeking to take the analysis a little further, we will try to characteristics for which the new developmental theory and the post Keynesian theory converge. As highlighted by Prado (2017) and Bresser-Pereira (2011a), the new developmentalism seems to present, in theoretical terms, as a junction of the Keynesian theory with the structuralist. First, we can already emphasize two common characteristics between the new developmentalism and the post Keynesian thought that are the approach on the demand side - with demand being the key variable for the func- 
tioning of the economy (demand determining supply) - and the intervention to ensure the volume of investment needed for emerging countries to achieve economic development. Another aspect that appears in both Kalecki (1966) and Bresser-Pereira's (2011a) new developmental theory is the preoccupation with inflationary pressures in the emerging economies search for the expansion of productive capacity.

Dealing more with the structuralist theory present within the new developmental notion, it is important to remember two characteristics in common with post Keynesian thought. First, both theoretical strands are not based on neoclassical microeconomic theory, adopting heterodox microeconomic theories to relate to their macroeconomic theories. Bresser-Pereira (2016) affirms that the new developmentalism would have its own microeconomics and post Keynesian theory - as highlighted by Lavoie (2007) - is also based on a microeconomy with principles quite distinct from neoclassical. Moreover, as pointed out by Fonseca and Mollo (2013), structuralists propose more than just counter-cyclical policies by the state to overcome structural problems, with long-term and persistent state actions being fundamental. Kalecki (1966) also emphasizes in his theory that the obstacles encountered in attempting to accelerate investment by the state in the objective of an emerging country to overcome its productive capacity deficiency, would be more manageable in the long term. This shows that both in Kaleckian thought and in structuralist thought present in the new developmentalism, there is an idea of structural change planning envisaged in the long term. It is also worth mentioning the search for an industrialization process focused on exports in the new developmentalism. This importance given to the industrialization process also appears in Kaldor's (1960) theory, which highlights the need for industrialization for the economic growth of underdeveloped countries. Thus, the question of the industrialization importance is also present in both the post Keynesian theory of Kaldor and in the new developmental theory.

With these characteristics, we can already perceive some convergent aspects between the post Keynesian theory and the new developmental theory. It is clear here that there are several common attributes between the new developmentalism and the post Keynesian theory (including fundamental principles that identify this theoretical strand with Kaleckian and Kaldorian work). Thus, a common core between post Keynesianism and new developmentalism can be pointed out, an intersection between the two theories, which contains the core of the concept of "post Keynesianism applied to emerging countries".

We have found a common core between the post Keynesianism and the new developmentalism, where these two theoretical frameworks share these three important attributes - industrialization, interventionism and national project. Although this paper focuses on ascertain the existence of common cores between strands of economic thought, it is worth mentioning here some differences between these two strands. Some of the most striking differences that can be stressed are related to the relevance of the exchange rate in the new developmentalism. The new developmental macroeconomics agrees with the principles of the Keynes's theory 
but add new facts to the Keynesian macroeconomics to compose its macroeconomic theory. Agreeing with Keynes, the new developmentalism begins from the notion that investment depends on the tradeoff between the interest rate (the capital cost) and the expected profit rate, going to his idea of investment function and economic growth - rejecting the Say's law, with an economic approach which assumes the existence of a demand insufficiency tendency once, according to Keynes, effective demand is important in the expected profit rate determination, but the effective demand may not be realized (Bresser-Pereira, 2017b).

The new developmentalism shares the Keynes's vision that investment and growth is not enough warranted by the demand, but (in the emergent countries) this is profoundly linked to the exchange rate. The new developmental theory includes the exchange rate in the investment function. According to this theoretical framework, the exchange rate (when it is overvalued in the long-term) denies or gives access to the existing demand for the competitive companies this rate can turn on or deprive this companies from the foreign and domestic markets. If the exchange rate is volatile (as considered for the liberal orthodoxy), this volatility will be just an additional factor of uncertainty for the business entrepreneur, affecting investment marginally. However, the new developmentalism shows that emerging countries have tendency to an overvaluation of the exchange rate, with the exchange rate remaining appreciated for many years between financial crises. In this case, when the entrepreneur makes his projections, he sees his production will not be competitive, so he does not make the investment (in some cases, he realizes investments to modernize his business, but not to expand the production). In this sense, is important stress an important characteristic: the new developmental theory criticizes the economic growth with foreign indebtedness (or foreign savings). This is consistent with the theory because when capital-rich countries inject capitals in poorcapital countries, it will be observed an overvaluation of the exchange rate, with the deficit in the current account. At the same time, the national currency is also appreciated because of the capital inflows needed to finance the current account deficit. So, the new developmentalism defends the economic growth without a foreign indebtedness policy, not incurring into current account deficits financed by loans or foreign direct investments.

This marks some important differences between post Keynesian theory and new developmental theory. Investment and growth do not depend on the exchange in the post Keynesian macroeconomics, once this theoretical framework assumes the volatility of the exchange rate. On the other hand, because of the chronic and cyclical overvaluation tendency of the exchange rate in the emergent countries, in the new developmentalism investment and growth are dependent of the exchange rate. Bresser-Pereira (2017b) highlights this happens because the Keynes work was focused in rich countries and not in developing countries, although Keynes knew how strategic the exchange rate was in the economic process. 


\section{CONCLUSION}

We began this article by pondering that our objective was, throughout the work, to present the main characteristics of the post Keynesian and developmental thoughts, so that, after exploring the characteristics of these two strands, we could verify possible convergences between them. Within this, it is important to point out some issues. In the first place, it is important to remember that within the developmental strands we are more attached to the new developmental discussion. Second, we must remember that when we approach the post Keynesian theory in this paper (except for some principles that are basic to this whole theory, which are highlighted in the first section), we are addressing post Keynesian theory regarding its analysis to emerging countries.

In this way, the objective here was to answer the following question: "Does post Keynesian theory, when contextualized in the context of economic underdevelopment, gain developmental outlines?". The answer to that question was "yes." After exposing various aspects of post Keynesian theory (with Kalecki and Kaldor as strong references in this section), developmental policies (as attributes common to all developmental strands), structuralist theory (which is present in the new developmental current) and new developmental theory, we could observe a considerable number of convergences between post Keynesianism and developmentalism. As was illustrated by Venn diagrams, with the exposed characteristics of the theoretical strands addressed, we can establish a common core between post Keynesianism and developmentalism - dealing here with developmentalism as a general concept - where the post Keynesian theory share the three attributes of the general concept of developmentalism established by Fonseca (2014). That would already answer the question.

However, using the discussed aspects of the new developmental theory, which could be treated as a kind of Keynesian-structuralist mix, we could also identify a common core between post Keynesianism and new developmentalism. Thus, we can say that these two strands also present a considerable number of convergent characteristics. Finally, once we have seen these common cores between post Keynesianism and developmentalism, and between post Keynesianism and new developmentalism, it has been possible to define that these intersections represented in the diagrams contain the intersection of the attributes (i) industrialization, (ii) interventionism and (iii) national project; which was called: the post Keynesianism applied to emerging countries.

\section{REFERENCES}

Bresser-Pereira, L.C. (2008) “The Dutch disease and its neutralization: a Ricardian approach” (2008) Brazilian Journal of Political Economy 28(1): 47-71.

Bresser-Pereira, L.C. (2009) "The two methods and the hard core of economics", Journal of Post Keynesian Economics 31 (3): 493-522. 
Bresser-Pereira, L.C. (2011) “Uma escola de pensamento keynesiano-estruturalista no Brasil?”, Revista de Economia Política, 31(2): 305-314.

Bresser-Pereira, L.C. (2012) “Structuralist macroeconomics and new developmentalism”, Brazilian Journal of Political Economy 32(3): 347-366.

Bresser-Pereira, L.C. (2016) "Reflexões sobre o Novo Desenvolvimentismo e o Desenvolvimentismo Clássico", Revista de Economia Política, 36(2): 237-265.

Bresser-Pereira, L.C. (2017a) "The two forms of capitalism: developmentalism and economic liberalism”, Brazilian Journal of Political Economy, 37 (4): 680-703.

Bresser-Pereira, L.C. (2017b) "The economics and the political economy of New-Developmentalism". São Paulo: FGV EESP (Working Paper Series n. 464).

Bresser-Pereira, L.C. (2018) "From classical developmentalism and post-Keynesian macroeconomics to new developmentalism”. (Forthcoming).

Bresser-Pereira, L.C.; J. L. Oreiro; N. Marconi (2014) Developmental Macroeconomics, London: Routledge.

Colander, D.; Holt, R.; Rosser, B. (2004) “The changing face of mainstream economics”. Review of Political Economy, 16(4): 485-499.

Davidson, Paul (2009) "Can future systemic financial risk be quantified? Ergodic vs nonergodic stochastic processes”, Brazilian Journal of Political Economy 29(4) October: 324-340.

Ferrari Filho, F. (1996) “'Keynesianos', monetaristas, novos-clássicos e novos-keynesianos: uma crítica pós-keynesiana”. Ensaios FEE 17(2): 78-101.

Fonseca, P. C. D.; Mollo, M. L. R. (2013) “Desenvolvimentismo e Novo-Desenvolvimentismo: Raízes Teóricas e Precisões Conceituais", Revista de Economia Política, 33(2): 222-239.

Fonseca, P. C. D. (2014) “Desenvolvimentismo: a Construção do Conceito”. In: Calixtre, A. B.; Biancarelli, A. M.; Cintra, M. A. C. (Orgs.). Presente e Futuro do Desenvolvimento Brasileiro. 1 ed. Brasília: IPEA: 29-78.

Harcourt, G. C.; Kriesler, P. (2013) The Oxford Handbook of Post Keynesian Economics, v.1. Oxford: Oxford University Press.

Herscovici, A. (2006) "A teoria dos fundos de empréstimos: um estudo dos modelos agregados Neoclássico e Keynesiano”. Análise Econômica 24 (46): 109-122.

Kaldor, N. (1960) Essays on Economic Stability and Growth. London: Duckworth.

Kalecki, M. (1966 [1983b]) "A diferença entre os problemas econômicos cruciais das economias capitalistas desenvolvidas e subdesenvolvidas”. In: Kalecki, M. Crescimento e ciclo das economias capitalistas. São Paulo: HUCITEC.

Lamonica, M. T.; Feijó, C. A. (2011) “Crescimento e industrialização no Brasil: Uma interpretação à luz das propostas de Kaldor”, Revista de Economia Política, 31(1): 1-20.

Lavoie, M (2007 [2009]) Introduction to Post Keynesian Economics. Palgrave Macmillan.

López, J. G.; Puchet, M. A.; Assous, M. (2009) "Michal Kalecki, um pioneiro da teoria econômica do desenvolvimento", Revista de Economia Política, 29(2): 191-211.

Mattei, L (2013) "Gênese e agenda do novo desenvolvimentismo brasileiro", Revista de Economia Política, 33(1): 41-59.

Prado, E. (2017) “Das explicações para a quase estagnação da economia capitalista no Brasil”, Revista de Economia Política, 37(3): 478-503.

Thirlwall, A. (1983) “A Plain Man's Guide to Kaldor's Laws”, Journal of Post Keynesian Economics, 5(3): 345-358. 